\title{
The Influence of Competence and Work Environment on Work Productivity through Work Motivation in Inpatient Rooms at Public Health Centre
}

\author{
Nirsah Fitriani, Baharuddin, Andi Tenri Fitriyah \\ Sekolah Tinggi Ilmu Ekonomi AMKOP Makassar, Indonesia \\ nirzahfitriani.13579@gmail.com, baharuddinamkop@gmail.com, Fitriyah.tenri@gmail.com \\ Yusriadi Yusriadi \\ Sekolah Tinggi Ilmu Administrasi Puangrimaggalatung, Makassar, Indonesia \\ yusriadi.yusriadi@uqconnect.edu.au \\ Saktiyadi \\ Sekolah Tinggi Ilmu Hukum Pengayoman, Makassar, Indonesia \\ saktiyadi010@gmail.com \\ Jafar \\ Baubau Islamic School of Religion (STAI) \\ jafaradzkia@gmail.com \\ Bazrul Makatita \\ Pasapua School of Health in Ambon \\ bazrulmakatita@gmail.com
}

\begin{abstract}
This research was conducted at the Public Health center inpatient room in Bissapu District, Bantaeng Regency. The sample used a purposive sampling method, namely sampling based on specific considerations or criteria. All models were 79 respondents in the Public Health center inpatient room in Bissapu District, Bantaeng Regency, which consisted of 2 health centers, namely the Bissapu Community Health Center and the Campagaloe Community Health Center. The data collection method used is direct interviews with the parties involved with the problem being discussed and giving questionnaires to nurses following the research. Data analysis was performed using descriptive analysis and path analysis. The results of the study show that: (1) competence and work environment affect work motivation in the Public Health center inpatient room in Bissapu District, Bantaeng Regency; (2) competence and work environment affect work productivity in the Public Health center inpatient room in Bissapu District, Bantaeng Regency; (3) work motivation affects work productivity in the Public Health center inpatient room in Bissapu District, Bantaeng Regency; (4) competence and work environment affect work productivity through work motivation in the Public Health center inpatient room in Bissapu District, Bantaeng Regency.
\end{abstract}

Keywords:

Competence, Work Environment, Work Motivation, Work Productivity

\section{Biographies}

Nirsah Fitriani is a student at Magister Program of Economic Science of STIE AMKOP, Indonesia. Her areas of interest and research include social science and economic. She has published some articles in national journals.

Baharuddin is a lecturer at Economics Department of STIE AMKOP, Indonesia. His areas of interest and research include economic, management, management human resource. He has published some books and many articles in national and international journals. 
Andi Tenri Fitriyah is a lecturer at Economics Department of STIE AMKOP, Indonesia. Her areas of interest and research include economic, management, management human resource. She has published some books and many articles in national and international journals.

Yusriadi Yusriadi is a lecturer at Public Administration Department of Sekolah Tinggi Ilmu Administrasi Puangrimaggalatung, Indonesia and chancellor on Sekolah Tinggi Ilmu Hukum Pengayoman. His areas of interest and research include social science, political science, sociology, legal studies, and public administration. He has published some books and many articles in national and international journals. He is a reviewer and editor in some local and international journals.

Saktiyadi is a lecturer and the head of the study program in at Department of Law at the Sekolah Tinggi Ilmu Hukum Pengayoman, Indonesia. His areas of interest and research include social science, political science, sociology, legal studies.

Jafar He is a lecturer at the YPIQ Baubau Islamic School of Religion (STAI). Currently, he is actively publishing his papers in national journals. He is an alumnus of Hasanuddin University Makassar in the field of Sociology. Currently, besides teaching at STAI, he is also a tutor at another campus in Baubau City.

Bazrul Makatita is a lecturer at the Pasapua School of Health in Ambon. Currently he is actively teaching in health sciences and currently he is actively researching health in the Covid-19 era. Currently he is in the category of a lecturer who is active in community service by always socializing about clean living in order to prevent the spread of Covid-19 in Maluku. 